\title{
Norwegian Family Forest Owners' Willingness to Participate in Carbon Offset Programs
}

\author{
Daniel E. Håbesland ${ }^{\mathrm{a}, *}$, Michael A. Kilgore ${ }^{\mathrm{a}}$, Dennis R. Becker ${ }^{\mathrm{a}}$, Stephanie A. Snyder ${ }^{\mathrm{b}}$,
} Birger Solberg ${ }^{c}$, Hanne K. Sjølie ${ }^{c}$, and Berit H. Lindstad ${ }^{c}$

\footnotetext{
${ }^{a}$ Department of Forest Resources, University of Minnesota, 115 Green Hall, 1530 Cleveland Avenue North, St. Paul, MN 55108, United States

${ }^{\mathrm{b}}$ USDA Forest Service, Northern Research Station, 1992 Folwell Avenue, St. Paul, MN 55108, United States

${ }^{\mathrm{c}}$ Department of Ecology and Natural Resource Management, Norwegian University of Life Sciences, P.O. Box 5003, 1432 Ås, Norway

* Corresponding author Email addresses: habes002@umn.edu (D. Håbesland), mkilgore@umn.edu (M. Kilgore), drbecker@umn.edu (D. Becker), stephaniesnyder@fs.fed.us (S. Snyder), birger.solberg@nmbu.no (B. Solberg), hanne.sjolie@nmbu.no (H. Sjølie), berit.lindstad@nmbu.no (B. Lindstad)
} 


\section{Introduction}

Forests act as carbon sinks and therefore play an important role in mitigating climate change, removing carbon from the atmosphere equivalent to about a third of the world's combined annual greenhouse gas emissions (Pan et al. 2011). Certain forest management practices can increase the amount of carbon stored in forests (Nunery and Keeton 2010; Ruddell et al. 2007) and potentially provide one of the lowest-cost and highest-volume opportunities for climate change mitigation (Galik et al. 2009; Gorte and Ramseur 2008). If policy mechanisms are in place, private forest owners can be compensated for undertaking management practices that increase the amount of carbon stored on their land. For instance, in California's cap-andtrade system, forest management projects that increase carbon sequestration can generate credits that can be sold to offset emissions elsewhere in the market (CARB 2014).

In Norway, a quarter of the land area is covered in productive forestland, and overall about $40 \%$ of the country is forested (Rognstad and Steinset 2011). In 2005, Norwegian forests sequestered 29.9 million tons $\mathrm{CO}_{2} \mathrm{e}$, which was equivalent to $55 \%$ of the country's anthropogenic greenhouse gas emissions that year (Norwegian Ministry of the Environment 2008). It has been estimated that forest management measures could increase sequestration of $\mathrm{CO}_{2}$ substantially, by up to 12.3 million tons per year over the next 100 years (Norwegian Climate and Pollution Agency 2010). Family forest owners own $80 \%$ of productive forestland in Norway and play a central role in the management of the country's forests (Rognstad and Steinset 2011). Thus, they also play an important role in Norway's efforts to reduce its net greenhouse gas emissions.

There is currently no policy mechanism in place to encourage increased carbon sequestration on private forestland in Norway or to allow Norwegian family forest owners to sell carbon credits. However, the topic is high on the political agenda, with several public reports and white papers discussing how Norwegian forests may contribute to climate change mitigation published during the past six years (Norwegian Climate and Pollution Agency 2010; Norwegian Ministry of Agriculture and Food 2009; Norwegian Ministry of the Environment 2012; Ministry of Climate and Environment 2015). Although the standing volume in Norway's forests is currently at a high due to intensive planting and afforestation between 1950 and 1990, forest growth and carbon sequestration is projected to decline in the future (Trømborg et al. 2011).

Family forest owners are a diverse group with a wide range of objectives, values, and attitudes that have been found to affect their management decisions (Becker et al. 2013; Bolkesjø et al. 2007; Butler et al. 2007; Finley and Kittredge 2006; Ingemarson et al. 2006; Karppinen 1998; Kline et al. 2000). If policymakers wish to implement programs aimed at increasing the amount of carbon sequestered in Norwegian forests, it is important to recognize the heterogeneity of family forest owners and the factors that influence their willingness to participate in such programs (Finley and Kittredge 2006). This study investigates the factors that affect whether Norwegian family forest owners would be willing to manage their forests for increased carbon sequestration and estimates the potential supply of forest carbon offsets from family forestlands in Norway.

\section{Background}

Only a handful of studies have quantitatively examined factors that influence family forest owner interest in participating in carbon offset programs. Three of these were carried out in Massachusetts, the first being a pilot study conducted by Fletcher et al. (2009), which was expanded on by Dickinson (2010) and Markowski-Lindsay et al. (2011). The studies used mail 
surveys to ask respondents to rate various hypothetical carbon sequestration programs according to how likely they would be to enroll the program. The programs varied in terms of several program attributes, such as expected payment, time commitment, whether or not a management plan was required, and whether or not there was a penalty for early withdrawal. The studies generally found that respondents preferred programs with higher expected payment, shorter time commitments, no management plan requirement, and no early withdrawal penalty, and suggest that certain landowner characteristics, such as having higher education and believing that forests can reduce climate change, increase the probability of participation. Overall, the three Massachusetts studies found that family forest owner participation would be quite low given program characteristics similar to those in existing carbon sequestration programs, and that nonmonetary factors played an important role in landowner decision-making.

Another study was conducted by Thompson and Hansen (2012) using data from a nationwide mail survey of 429 U.S. family forest owners. The survey asked questions gauging respondents' attitudes toward potential economic and environmental impacts of participating in carbon sequestration and trading, as well as questions about the respondent's land characteristics, land-use planning, and demographic information. A cluster analysis revealed two distinct clusters of positive and negative attitudes among respondents about managing their forest for carbon sequestration and trading. Respondents in the positive attitude cluster tended to own smaller parcels and actively manage their forest.

Miller et al. (2012) conducted a study examining the factors influencing landowner participation in forest carbon offset programs in Michigan, Wisconsin, and Minnesota. The study used a mail-back questionnaire that posed a dichotomous choice question about whether respondents would enroll in the program given a specified per acre payment and contract length. The questionnaire also included questions about ownership objectives and practices, forestland characteristics, attitudes towards climate change, familiarity with carbon markets, and landowner demographics. The study found that many landowners would be interested in participating given favorable financial conditions and short contract periods, particularly absentee owners who owned larger parcels and had already completed some of the carbon program requirements. Landowners were also more likely to participate if they had positive attitudes towards using forests to mitigate climate change and if they greatly valued the non-market amenities of their forest.

In general, these previous studies show that landowners are sensitive to program requirements and conditions. As one might expect, they prefer programs with higher compensation amounts and less stringent requirements regarding the time commitment, early withdrawal, and management plans. However, the studies also suggest that landowner interest in carbon programs is primarily motivated by non-monetary factors, and that active forest managers with higher education and who believe that forestry can play an important role in mitigating climate change may be more likely to participate in carbon programs.

As only a small number of studies on family forest owner interest in carbon programs have been conducted, there are important knowledge gaps that need to be addressed. All of the studies so far have been conducted in the United States, and as Markowski-Lindsay et al. (2011) point out, forest ownership trends and behavior are likely to vary by region. More studies need to be conducted in other parts of the world to better understand how regional differences affect landowner decision-making, particularly as emissions trading and carbon offsetting opportunities continue to develop. 
The studies that have been conducted so far have also had samples dominated by relatively small landowner holdings. For instance, Markowski-Lindsay et al. (2011) and Miller et al. (2012) had mean parcel sizes of 48 acres (19 hectares) and 63 acres (25 hectares) respectively. While small acreage landowners make up the largest number of family forest owners in the respective study regions, they do not necessarily account for the largest share of the total forestland or those landowners who might be most inclined to participate. To estimate the total potential increase in carbon sequestration from a national carbon program in Norway, it is important to understand what influences the behavior of large acreage landowners as well. This study attempts to address both of these knowledge gaps.

\section{Data and methods}

\subsection{Survey development}

A mail survey was developed to investigate Norwegian family forest owners' interest in participating in carbon offset programs. The survey was based on the one used by Miller et al. (2012), but underwent extensive review with Statistics Norway and was modified to ensure that the tone and content of the questions were appropriate for Norwegian landowners. The survey was mailed out to a random sample of 1,500 landowners who owned at least eight hectares of forestland in Norway. The sample was stratified by property size, using three size classes: 8.049.9 ha, 50.0-99.9 ha, and >99.9 ha. The sample in each size class was drawn proportional to the total forest area in each size class. This was done to generate an overrepresentation of large acreage forest owners. Three mailings were sent beginning in April 2013, following the Total Design Method (Dillman 1978). Each mailing included a personally addressed cover letter, the full survey, and a pre-paid return envelope. Surveys returned by August 1, 2013 were considered for analysis.

The survey presented respondents with a hypothetical carbon program that varied in terms of the number of years a respondent would be required to participate $(10,25$, or 50 years) and the payment amount they would receive per hectare per year $(50,200,400$, or $600 \mathrm{NOK}) .{ }^{1}$ Twelve versions of the survey were created using combinations of the three different contract lengths and the four different payment amounts. Respondents were provided information about several management actions they would need to undertake in order to participate, such as having a forest management plan prepared, having the forest certified by an independent third party, and carrying out management actions that increase carbon sequestration in the forest. It was made clear that these management actions would depend on the specific conditions of the landowner's forest and could include harvesting more or less timber, increasing tree planting, or increasing fertilization. Respondents were then presented with a dichotomous choice question asking whether they would participate in the program given the conditions outlined above. The survey did not ask respondents how intensively they would undertake the management actions increasing carbon sequestration or how much of their land they would be willing to enroll in a carbon program. It was assumed a landowner would enroll the entire forest property in the carbon program and undertake the management actions needed to sell forest carbon offsets.

Several studies have found that contingent valuation studies exhibit hypothetical bias both when estimating willingness to pay and willingness to accept (Blumenschein et al. 1998; Champ and Bishop 2001; Champ et al. 1997; List and Gallet 2001; Murphy et al. 2005). This

\footnotetext{
${ }^{1}$ These payments correspond to approximately 6, 26, 51, and 77 USD per hectare per year, given an exchange rate of $7.8 \mathrm{NOK} / \mathrm{USD}$.
} 
means that while some respondents may state that they would be willing to accept the contract conditions and participate in the hypothetical carbon program, if they were faced with the actual decision they may instead be uncertain or unwilling to participate. In this study, there a couple reasons respondents may have been uncertain about their response to the dichotomous choice question. Some respondents may have felt they had not been given enough information about the carbon program in order to make an informed decision. Additionally, respondents who were offered a payment amount close to their reservation price (i.e. the lowest amount of compensation they would have been willing to accept) would have been more uncertain about their response than respondents who were offered a payment amount much higher or lower than their reservation price. Studies have found that explicitly asking respondents about the certainty of their response can allow researchers to better estimate actual behavior (Champ and Bishop 2001; Champ et al. 1997). Therefore, following the dichotomous choice question, respondents were asked two questions about how confident they felt in their answer using a five-point rating scale. The first question asked how certain they were given the conditions in the contract, and the second question asked how certain they were given the information they had received about the carbon program.

The survey also asked several questions about the respondent's objectives (e.g. reasons for owning forestland, past and planned management actions) and attitudes (e.g. importance of various forest characteristics, perceived barriers to participation, attitudes towards climate change and using forests to mitigate climate change). Finally, the survey included several questions about the respondent's demographic information (e.g. age, gender, education, residential information).

\subsection{Model development}

A random utility model (Hanemann 1984) provides the theoretical basis for estimating Norwegian family forest owner interest in participating in carbon programs. The survey data were analyzed using a binary logistic regression model, and all computations were done using the statistical software R version 3.1.0. The dependent variable was the respondent's answer to the dichotomous choice question, which took on the value of " 1 " if the respondent was willing to accept the conditions and participate in the carbon program, and " 0 " if the respondent was not willing to participate. The model takes the general form:

$\operatorname{logit}\left(Y_{i}\right)=\ln \left(\frac{p_{i}}{1-p_{i}}\right)=\alpha+\beta^{\prime} X_{i}$

Where:

$Y_{i} \quad$ outcome of interest (whether a landowner will participate in the carbon program)

$p_{i} \quad$ probability of outcome

$\alpha \quad$ intercept

$\beta$, vector of regression coefficients

$X_{i} \quad$ vector of predictor variables (e.g. payment amount, parcel size, past harvesting, etc.)

Eq. (1) can be rewritten to allow us to estimate the probability of occurrence of the outcome of interest (Peng et al. 2002):

$\mathrm{P}\left(Y_{i}=1 \mid X_{i}\right)=\frac{e^{\alpha+\beta^{\prime} X_{i}}}{1+e^{\alpha+\beta^{\prime} X_{i}}}=\frac{1}{1+e^{-\left(\alpha+\beta^{\prime} X_{i}\right)}}$ 
Existing literature on family forest owners was used to inform the decision about which predictor variables to include in the model and their hypothesized effect on participation in carbon programs. These variables can be grouped into three categories: carbon program characteristics, forestland characteristics, and landowner characteristics (Table 1).

Previous studies on carbon programs and incentive programs for other ecosystem services suggest that payment amount and contract length are important program characteristics and were included in the model. Several studies have demonstrated a positive relationship between the payment amount offered and participation (Dickinson et al. 2012; Fletcher et al. 2009; Kilgore et al. 2008a; Kline et al. 2000; Layton and Siikamäki 2009; Markowski-Lindsay et al. 2011; Miller et al. 2012; Rabotyagov and Lin 2013; Sullivan et al. 2005). Payment amount (PAYMENT) was therefore hypothesized to have a positive effect on participation. Most studies have found that landowners prefer shorter contract lengths (Dickinson et al. 2012; Layton and Siikamäki 2009; Markowski-Lindsay et al. 2011; Miller et al. 2012; Rabotyagov and Lin 2013), and contract length (YEARS) was therefore hypothesized to have a negative effect on participation.

Two forestland characteristics were hypothesized to affect participation: total amount of forestland owned and whether the landowner had harvested timber in the past. The literature suggests that the impact of forest size is somewhat mixed, with most studies on carbon programs finding forest size to have no effect, or a marginally significant positive effect (Dickinson et al. 2012; Markowski-Lindsay et al. 2011; Miller et al. 2012). Thompson and Hansen (2012) found that larger landowners tend to have more negative attitudes towards carbon sequestration and trading. For other types of incentive programs, some studies found total forest size to positively affect participation (Kilgore et al. 2008b; Lindhjem and Mitani 2012; Mäntymaa et al. 2009; Sullivan et al. 2005), while others found it to have a negative effect (Kline et al. 2000; Rabotyagov and Lin 2013). Total forestland owned (HECTARES) was therefore included in the model with an uncertain hypothesized effect. Whether the landowner had harvested in the past (HARVEST) was included as an indicator of whether the forest was being actively managed (Butler et al. 2007). The hypothesized effect on participation was positive, as it has been suggested that landowners already actively managing their forests are more willing to take the management actions required to participate in carbon programs (Markowski-Lindsay et al. 2011).

Several landowner characteristics were also included in the model. Gender (MALE) was included, although the literature suggests the role of gender is mixed. While Miller et al. (2012) found that men were more likely to participate in carbon programs, Dickinson et al. (2012) found that women were more likely to participate. The hypothesized effect of gender was therefore uncertain. Several studies suggest that landowner education level has a positive effect on participation in carbon markets (Dickinson et al. 2012; Markowski-Lindsay et al. 2011; Thompson and Hansen 2012). A variable indicating whether the landowner has education beyond the high school level (HIGHER.ED) was included and hypothesized to have a positive effect on participation. Length of ownership, in years, (TENURE) was also included in the model with a negative hypothesized effect, as some studies have found evidence suggesting that land tenure may have a negative effect on participation in carbon programs (Miller et al. 2012) and conservation programs (Rabotyagov and Lin 2013). Residing on the forestland (RESIDE) was also thought to affect participation, though the hypothesized effect was uncertain. Miller et al. (2012) found that absentee owners were more interested in participating in carbon programs, while Thompson and Hansen (2012) found that absentee owners were less likely to participate. 
Kilgore et al. (2008a) found that landowners were more likely to participate in an incentive program if they were familiar with it prior to receiving the survey, so a categorical variable indicating level of familiarity with managing forests for carbon sequestration (FAMILIARITY) was included and hypothesized to have a positive effect on participation.

Family forest owners have diverse motivations for owning forestland, many of which involve non-timber values (Butler et al. 2007; Kline et al. 2000). Miller et al. (2012) found that landowners who place importance on generating non-timber income from their land were more interested in selling carbon credits. A categorical variable indicating the importance of generating non-timber income (e.g. hunting and fishing licenses, rent from cabins) from the forestland (OTHER.INCOME) was therefore included and hypothesized to positively affect participation. Managing forests for carbon sequestration also has the potential to enhance other non-market amenities in a forest compared to traditional timber management. The Norwegian landowner survey listed a few of these, specifically soil and water quality, biodiversity, and aesthetics, and asked respondents to rate, on a 5-point rating scale, how important each of these forest characteristics was to them. Miller et al. (2012) found that landowners who place a high level of importance on these non-market amenities are more likely to participate in carbon programs. A composite score (NON.MARKET), which averaged the importance of each of the three non-market forest amenities, was therefore included in the model and hypothesized to positively affect participation.

Participating in a carbon program would require a landowner to take specific management actions to increase carbon sequestration on their land, which may present barriers to participation. The survey presented respondents with ten such potential management actions, including having the forest certified, accepting regular monitoring and verification, and harvesting less timber than planned. Respondents rated the extent to which each management action presented a barrier to participation on a 5-point rating scale. A composite score (BARRIERS), which averaged the ratings, was included in the model and hypothesized to negatively affect participation, as was found by Miller et al. (2012). Other studies have found that landowners are less interested in participating in carbon programs that require management plans and establishing additionality, which would also support this hypothesis (Dickinson et al. 2012; Markowski-Lindsay et al. 2011).

Finally, it was hypothesized that landowners who believe climate change is an important concern and that forests can play an important role in mitigating climate change would be more interested in participating (Markowski-Lindsay et al. 2011; Miller et al. 2012). Respondents were asked to rate on a 5-point rating scale, their level of agreement with three statements: that humans have contributed to climate change, that forests can play an important role in mitigating climate change, and that they own enough forest for it to be worthwhile to manage for carbon. A composite score (CO2.COMP), which averaged their level of agreement with these statements, was included with a positive hypothesized effect.

\subsection{Data inspection}

Before conducting the analysis, the suitability of logistic regression as an analysis method was assessed. As shown in Eq. (1), logistic regression assumes that the log odds ratio is linearly related to the predictor variables. To check this linearity assumption, each continuous and categorical predictor variable was binned, and the log odds ratio was plotted for each bin. All but two variables were found to adequately meet the linearity assumption without needing transformations. The variables PAYMENT and HECTARES were found to meet the linearity 

variables InPAYMENT and InHECTARES were included in the model instead.

As is common with voluntary surveys, many respondents did not fill out responses to every item in the survey. About two-thirds of respondents answered all items that were included as variables in the model. Overall, about $5 \%$ of the items for the model variables were missing. Although a common method for dealing with missing data is listwise deletion, which involves eliminating an entire observation if any entries are missing, this method results in the loss of valuable information and a potential selection bias, as it assumes data is missing completely at randomly (MCAR) (King et al. 2001). To test, a Little's MCAR test was run, giving a Chisquared of 3439.742 on 3240 degrees of freedom, and a p-value of 0.007 . The null hypothesis that the data is MCAR was therefore rejected, suggesting that listwise deletion could indeed lead to biased results.

One of the most highly recommended methods for dealing with missing data in the social sciences is multiple imputation (King et al. 2001; Little et al. 2014; Manly and Wells 2012; Schafer and Graham 2002). Multiple imputation uses the distribution of the observed data to estimate plausible estimates for the missing values. Multiple datasets are created, each of which is slightly different due to random components that reflect the uncertainty in the values (White et al. 2011). Each dataset is analyzed individually and the results are combined using the rules outlined by Rubin (1987) to obtain overall coefficients and standard errors. The R package Amelia II (Honaker et al. 2011) was used to create 10 multiply imputed datasets, and the R package Zelig (Owen et al. 2013) was used to analyze the datasets and combine results.

\section{Results}

\subsection{Survey response rate}

Of the 1,500 surveys mailed to Norwegian family forest owners, seven were undeliverable and 15 were incorrectly sampled (e.g. recipient was deceased or no longer owns forest property), giving an adjusted sample size of 1478. A total of 841 surveys were returned, of which 831 were considered usable for the analysis. Only surveys that were returned completely blank or where the respondent indicated they did not own forestland were removed before conducting the analysis. In addition, there were 25 responses from landowners who did not wish to participate. This gave an overall response rate of $59 \%$, and a usable response rate of $56 \%$.

This response rate is high compared to other surveys of family forest owners, which tend to be in the range of $32 \%$ to $67 \%$ (Butler et al. 2007; Dickinson et al. 2012; Kendra and Hull 2005; Kilgore et al. 2008b; Markowski-Lindsay et al. 2011; Miller et al. 2012; Rasamoelina et al. 2010). Few surveys of Norwegian family forest owners have been conducted previously, however a survey examining their willingness to accept compensation for voluntary conservation achieved an overall response rate of 38.5\% (Lindhjem and Mitani 2012).

\subsection{Sample description}

The mean respondent was 55 years old, owned 319 hectares of forestland (median forest size was 150 hectares), and had owned their forest property for 22 years. About $83 \%$ of respondents were male, $43 \%$ had completed some higher education, and $82 \%$ resided on or within $10 \mathrm{~km}$ of their forestland. Respondents tended to be active forest managers, with about $73 \%$ being members of forest owner associations and $78 \%$ having harvested timber for sale since owning the property. The most important reasons for forest ownership were "Heritage/family tradition," "Part of farm or other property," and "Timber income." 
Overall, $48 \%$ of respondents indicated that they would be interested in participating in a carbon program, given the contract conditions offered. Respondents cited fertilizing more and changing harvesting practices as the largest barriers to participation in carbon programs. On the other hand, getting their forest certified, having an inventory and management plan prepared, and implementing measures in the management plan were not seen as particularly large barriers. This is likely due to the fact that the sample consisted largely of active landowners, and each of these three measures had already been completed by between $60 \%$ and $67 \%$ of respondents during the past 10 years.

With regards to their attitudes about using forests to mitigate climate change, $41 \%$ of respondents said they completely agree ( 5 on a 5 -point rating scale) that humans have contributed to climate change, $42 \%$ completely agree that forestry can play an important role in mitigating climate change, while only $15 \%$ completely agree that they own enough forest for it to be worthwhile to implement measures to mitigate climate change on their land.

\subsection{Checking for non-response bias}

In order to check for potential non-response bias, respondents were compared to those who did not return the survey. Statistics Norway provided data on selected variables for the entire population of family forest owners, the gross sample (i.e. all the landowners in the sample), and the net sample (i.e. all landowners who returned the survey) (Table 2). These data show that respondents were more likely to be male, have harvested timber, and own more forestland than non-respondents. As this study purposefully oversampled large acreage landowners and thereby also more active landowners, this means these landowners are even more overrepresented in the net sample. Respondents were very similar to non-respondents, and the population, in terms of age and living on the forest property.

\subsection{Logistic regression models}

The logistic regression model was run on four different subsets of respondents. Model 1 included all respondents and modeled factors that were hypothesized to affect overall interest in participating in carbon programs in the sample. Guided by studies that examined the potential for hypothetical bias in contingent valuation studies (Champ and Bishop 2001; Champ et al. 1997), Model 2 includes only respondents who indicated they were highly certain about their response to the dichotomous choice question (i.e. whether or not they would participate in the carbon program given the contract conditions they were offered). Responses to the two certainty questions were averaged, and a cutoff of $>=4$ on the five-point rating scale was used to determine whether or not the respondent was certain of their response. The choice for the cutoff was informed by Champ and Bishop (2001), who found that stated behavior was most similar to actual behavior when only responses with eight or more on a 10-point certainty scale were considered valid. By only including respondents who are highly certain of their response, Model 2 minimizes the potential for hypothetical bias and may improve estimates of participation in an actual carbon program.

Because the sample was stratified to give an overrepresentation of large forest owners, this allowed us to run a separate model on their responses, something that has not been done in previous studies on family forest owner participation in carbon programs. Model 3 included only landowners who own more than 150 hectares of forestland, and Model 4 included only landowners who own 150 hectares or less of forestland. Descriptive statistics for the sample subsets used each model are shown in Table 3. 


\subsection{Significant predictors of participation}

Table 4 reports the coefficients and standard errors of the logistic regression analyses. The payment amount offered (PAYMENT) is highly significant in all of the models and has a positive coefficient as expected. The contract length required (YEARS) has a negative coefficient as expected, however, it is not statistically significant in any of the models. The amount of forestland owned (HECTARES) only has a marginally significant positive affect on participation in Model 1, while having harvested previously (HARVEST) is significant in Model 3 , but with a negative coefficient, opposite of what was hypothesized.

Of the landowner characteristics, only four were found to be significant in any of the models. Having higher education (HIGHER.ED) has a positive impact on participation in three of the models. Placing importance on non-market values (NON.MARKET) negatively influences participation in three of the models, contrary to the hypothesized effect. Perceived barriers to participation (BARRIERS) and attitudes towards using forests to mitigate climate change (CO2.COMP) are significant in all four models, both with the hypothesized effect on participation.

Table 5 reports the marginal effects of each variable in the four models. Marginal effects indicate the change in probability of participation associated with a one unit increase in a continuous explanatory variable or a change from 0 to 1 in a binary explanatory variable. For instance, marginal effects on BARRIERS in Model 1 indicate that a 1 point increase in the composite score would decrease the probability of participation by about $37 \%$. The marginal effects on HIGHER.ED in Model 1 indicate that a respondent with higher education is about $12 \%$ more likely to participate than a respondent without higher education. For the logtransformed variables lnPAYMENT and lnHECTARES, the marginal effects indicate the change in probability of participation associated with the variable increasing by a factor of $e$ (the base of the natural logarithm, approximately equal to 2.718). In other words, based on Model 1, increasing the payment amount offered by a factor of 2.718 increases the probability of participation by about $11 \%$. All marginal effects are estimated using the means of each explanatory variable for that sample subset.

\section{Discussion}

\subsection{Comparing models}

The models presented in Table 4 and Table 5 examine four important dimensions of Norwegian family forest owners. Generally, the results of the logistic regression analysis are quite consistent across the four models. Several variables are significant in most or all of the models, and the signs of the coefficients of the significant variables are consistent across all models. A couple variables, however, are only significant in one or two of the models.

Comparing Model 1 and Model 2 shows that there is little difference between all respondents and those who are certain of their participation in a carbon program. The main difference is that the amount of forestland owned is a marginally significant predictor in Model 1 , but is not significant in Model 2. Additionally, all the significant coefficients have a greater magnitude in Model 2, meaning the variables have a greater impact on participation when looking only at respondents certain of their participation. Overall, the comparison between these two models suggests that any potential hypothetical bias does not significantly affect the predictors of participation, but may have some effect on the estimated level of family forest owner participation in a carbon offset program. 
The coefficient on forest size was only marginally significant in Model 1 and not significant in Model 2, suggesting that there is not much difference between large and small acreage landowners in terms of their overall interest in participating in carbon programs. However, by comparing Model 3 and Model 4 it is clear that there are some differences in the factors that influence interest in participation between the two groups. If a large acreage landowner has harvested timber in the past and greatly values non-market forest amenities, he or she is significantly less likely to participate. This is not true for small acreage landowners, as these variables are insignificant in Model 4. On the other hand, having higher education increases the probability of participation for small acreage landowners but not large acreage landowners.

\subsection{Unexpected findings}

Several of the model variables were found to have a different effect on participation than hypothesized. The required contract length was not found to be significant in any of the models, suggesting that Norwegian landowners are not particularly averse to long time commitments. This contrasts earlier studies that have generally found that longer time commitments have a significant negative effect on participation in carbon programs and other incentive programs. A possible explanation for this is that Norwegian landowners have longer planning horizons than landowners in previous study areas. Most forest properties in Norway are a part of a farm that has been passed down from generation to generation, and long-term considerations are of great importance to Norwegian forest owners (Nordic Family Forestry 2015; Rognstad and Steinset 2011). Thus, Norwegian landowners may not be as concerned about the implications of a time commitment on the possibility of selling the land in the future as landowners in other regions.

Another unexpected finding was that large acreage landowners who had harvested timber for sale in the past were less likely to participate than those who had not. Although the hypothesis was that landowners who were already actively managing their land and selling timber would be more willing to take the actions necessary to participate in carbon programs, it appears that some groups of Norwegian landowners see carbon sequestration and timber production as conflicting goals. This finding may be a result of the sample, which oversampled large acreage landowners and has a high proportion of landowners actively harvesting timber.

The importance placed on non-market forest amenities also had an effect opposite of what was hypothesized. It was expected that landowners who greatly valued non-market forest amenities to be more interested in managing for carbon, however, the results show the opposite effect. This suggests that Norwegian landowners see carbon management and the protection or enhancement of non-market amenities as competing objectives. This could be due to a view among Norwegian landowners that participation in carbon programs would require intensive management and that non-market amenities are best protected when the forest is left untouched. In the recent public discussion in Norway, proposals to increase carbon sequestration in forests have focused on planting fast growing species, increasing stand density, and targeted fertilization (Norwegian Ministry of the Environment 2012). Landowners who greatly value the non-market amenities on their forestland may be opposed to these types of management actions, and thus less interested in participating in a carbon program.

Additionally, several landowner characteristics were found not to be significant predictors of participation. Although landowners with a long land tenure were not found to be significantly less interested in participating as hypothesized, some other studies have also found length of ownership to not influence participation in carbon programs (Fletcher et al. 2009; 

to be a significant predictor of participation. While this was somewhat unexpected, Miller et al. (2012) also found that familiarity with carbon offsets did not influence probability of participation. Finally, the importance placed on non-timber income from their forestland was not found to be a significant variable. A positive effect on participation was expected, however, the results suggest that Norwegian landowners may not view income from carbon offsets as an additional source of income in the same way as rent from hunting, fishing, or cabins, but rather as an alternative to timber income.

\subsection{Estimated participation}

When Model 1 is evaluated at the sample mean for each explanatory variable it predicts an overall level of participation of 46\%. A payment amount of 324 NOK (42 USD) per hectare per year would be required to achieve $50 \%$ participation. Model 2, using only respondents that were highly certain of their response, predicts an overall level of participation of $37 \%$. In Model 2, a payment of 411 NOK (53 USD) per hectare per year would be required to achieve 50\% participation. Figure 1 shows the estimated participation at each of the four payment amounts offered for Model 1 and Model 2. All other explanatory variables are held at their mean values. Participation ranges from about $30 \%$ at the lowest payment amount to about $57 \%$ for the highest payment amount in Model 1, and from about 14\% to 58\% in Model 2.

The overall estimated participation is relatively high compared to that found in earlier studies. Fletcher et al. (2009) estimated a participation rate of 5\% at a payment of 15 USD per acre (37 USD per hectare) per year and 33\% at a payment of 50 USD per acre (123 USD per hectare) per year. Markowski-Lindsay et al. (2011) estimated participation to be between $2 \%$ and $4 \%$ for a program with strict requirements and offering 10 USD per acre (25 USD per hectare) per year and between $36 \%$ and $38 \%$ for a program with lenient requirements and offering 1000 USD per acre (2471 USD per hectare) per year. Dickinson et al. (2012) estimated participation to be about $7.5 \%$ for with strict requirements and offering 8 USD per acre per year (20 USD per hectare) and $43 \%$ for a program with lenient requirements and offering 30 USD per acre (74 USD per hectare). These participation rates are all significantly lower than those found in this study. Miller et al. (2012) estimated that 18 USD per acre (44 USD per hectare) per year would be required to achieve a 50\% participation rate using a model with all respondents, and 28 USD per acre (69 USD per hectare) for a model using only certain respondents. These values are very similar to the ones found in this study.

In addition to payment amount offered, perceived barriers and attitudes towards climate change were found to be the most significant predictors of participation. Respondents who view every potential measure they might be required to take as posing a "large barrier" (giving a mean composite score of 5 on a 5-point rating scale), would only a participation rate of between $1 \%$ and $3 \%$ depending on the payment amount offered. In contrast, respondents who view every potential measure as posing "no barrier" (mean composite score of 1) would have a participation rate between $80 \%$ and $92 \%$, clearly illustrating the highly significant effect perceived barriers has on participation.

The composite variable CO2.COMP, also has a significant impact on participation as well, although not as extreme as that of the variable BARRIERS. Respondents who "completely agree" with the statements that humans have contributed to climate change, that forests can help mitigate climate change, and that they own enough forestland for carbon sequestration efforts to be worthwhile (giving a mean composite score of 5 on a 5-point rating scale), have participation 
rates ranging from $44 \%$ to $70 \%$ depending on the payment amount offered. In contrast, respondents who "completely disagree" (mean composite score of 1) with the statements have estimated participation rates between $14 \%$ and $33 \%$.

\section{Conclusion}

Family forestland in Norway has the potential to provide a significant reduction in the country's net greenhouse emissions. However, if a policy aimed at increasing carbon sequestration in these forests is to be implemented, it is important to understand the factors that influence whether landowners would be interested in participating.

The findings of this study suggest that there is a considerable amount of interest among Norwegian family forest owners to participate in carbon programs, more so than has been found in earlier studies in other regions. In the sample, $48 \%$ of respondents indicated they would be interested in participating given the contract conditions they were offered. The actual level of participation in a carbon program would depend greatly on the characteristics of the program, in particular the payment amount offered and management actions landowners would need to take in order to participate. Of these potential management actions, Norwegian landowners seem to be the most reluctant to fertilizing and changing their harvesting practices. On the other hand, it does not appear that long contract periods would significantly discourage participation.

The results of the preceding analysis have important implications for policymakers and others interested in developing carbon offset programs in Norway. If the goal is to generate substantial participation and a resulting supply of carbon offsets, prices will need to be sufficiently high and a balance will need to be found such that contract requirements ensure that the program is effective and credible in establishing additionality, while not imposing too great of a barrier to landowners. In particular, policymakers may wish to allow for flexibility in terms of the silvicultural measures landowners can take to increase carbon sequestration on their land, while stricter requirements regarding certification, management plans, and long contract lengths would likely not be seen as significant barriers for Norwegian landowners. This study also found that the extent to which landowners believe humans are contributing to climate change and that forestry can help mitigate climate change significantly influences their interest in participating. Because this is such a strong motivating factor for participation, is important that any carbon program is marketed to landowners in terms of its ability to contribute to mitigating climate change.

It also appears that some Norwegian landowners see managing their forest for carbon as conflicting with the goals of timber harvesting and/or protecting non-market amenities, as both these variables had negative coefficients in one or more of the models. If policymakers wish to encourage participation in a potential carbon offset program, it will be important to work with landowners to find ways in which carbon management can be compatible with both these goals and market the carbon program to appeal to landowners who view these as important objectives. There are various ways to increase carbon sequestration on forestland depending on the existing forest conditions, and landowners may see some of these as less conflicting with their management objectives than others. Once again, giving landowners some flexibility in terms of the management actions they can take as a part of the program could encourage participation significantly.

While the perception of barriers was an important predictor of participation, not much is known about why respondents viewed certain management actions as barriers. These measures may pose a financial burden to the landowner, they may conflict with other management 

participating in such a program. For this reason it is difficult to know for certain how these perceived barriers can be overcome and whether additional financial or technical assistance would make landowners more likely to participate. More research is needed to fully understand how specific program requirements are perceived by landowners and how programs can be designed to encourage participation. Additionally, more research is needed to better understand not only whether or not a landowner would be willing to participate, but also factors such as how intensively they would be willing to implement management actions or how much of their forestland they would be willing to enroll in the program.

This study contributes to the existing literature on family forest owner interest in carbon programs by looking at a geographic area outside the United States, where all previous studies of this type have been conducted. More studies from other regions are needed to fully understand the potential for carbon sequestration from family forestlands and the factors that influence landowner participation. There is also a need for comparisons between regions to better understand important similarities and differences in landowner interest in carbon programs, the factors driving those similarities and differences, and the implications for policymakers in the respective regions.

\section{Acknowledgements}

Funding for this project was provided in part by the Norwegian Centennial Chair Program, which is a joint research and academic venture between the Norwegian University of Life Sciences, University of Oslo, and the University of Minnesota. Partial funding was also provided by the U.S. Department of State through the Fulbright Scholar Program, the University of Minnesota's Agricultural Experiment Station (projects 42-054 and 42-050), the Norwegian Research Council project CenBio, and basic funding from the Norwegian University of Life Sciences. In-kind support from the USDA Forest Service, Northern Research Station is gratefully acknowledged.

\section{References}

Becker, D.R., Eryilmaz, D., Klapperich, J.J. and Kilgore, M.A. 2013. Social availability of residual woody biomass from nonindustrial private woodland owners in Minnesota and Wisconsin. Biomass and Bioenergy 56:82-91.

Blumenschein, K., Johannesson, M., Blomquist, G.C., Liljas, B. and O'Conor, R.M. 1998. Experimental Results on Expressed Certainty and Hypothetical Bias in Contingent Valuation. Southern Economic Journal 65(1):169-177.

Bolkesjø, T.F., Solberg, B. and Wangen, K.R. 2007. Heterogeneity in nonindustrial private roundwood supply: Lessons from a large panel of forest owners. Journal of Forest Economics 13(1):7-28.

Butler, B.J., Tyrrell, M., Feinberg, G., VanManen, S., Wiseman, L. and Wallinger, S. 2007. Understanding and Reaching Family Forest Owners: Lessons from Social Marketing Research. Journal of Forestry 105(7):348-357. 
California Air Resources Board (CARB). 2014. Compliance Offset Protocol U.S. Forest Projects. California Environmental Protection Agency, Air Resources Board, Sacramento, CA

Champ, P.A. and Bishop, R.C. 2001. Donation Payment Mechanisms and Contingent Valuation: An Empirical Study of Hypothetical Bias. Environmental and Resource Economics 19:383402.

Champ, P.A., Bishop, R.C., Brown, T.C. and McCollum, D.W. 1997. Using Donation Mechanisms to Value Nonuse Benefits from Public Goods. Journal of Environmental Economics and Management 33:151-162.

Dickinson, B.J. 2010. Massachusetts Landowner Participation in Forest Management Programs for Carbon Sequestration: An Ordered Logit Analysis of Ratings Data. M.Sc. Thesis, University of Massachusetts, Amherst.

Dickinson, B.J., Stevens, T.H., Markowski Lindsay, M. and Kittredge, D.B. 2012. Estimated participation in US carbon sequestration programs: A study of NIPF landowners in Massachusetts. Journal of Forest Economics 18(1):36-46.

Dillman, D.A. 1978. Mail and Telephone Surveys: The Total Design Method. New York: John Wiley \& Sons.

Finley, A.O. and Kittredge, D.B. 2006. Thoreau, Muir, and Jane Doe: Different Types of Private Forest Owners Need Different Kinds of Forest Management. Northern Journal of Applied Forestry 23(1):27-34.

Fletcher, L.S., Kittredge, D. and Stevens, T. 2009. Forest Landowners' Willingness to Sell Carbon Credits: A Pilot Study. Northern Journal of Applied Forestry 26(1):35-37.

Galik, C.S., Mobley, M.L. and Richter, D. 2009. A virtual "field test" of forest management carbon offset protocols: the influence of accounting. Mitigation and Adaptation Strategies for Global Change 14(7):677-690.

Gorte, R.W. and Ramseur, J.L. 2008. Forest Carbon Markets: Potentials and Drawbacks. CRS Report for Congress, RL34560. Congressional Research Service, Washington, DC.

Hanemann, W.M. 1984. Valuation Contingent Experiments in Responses. American Journal of Agricultural Economics 66(3):332-341.

Honaker, J., King, G. and Blackwell, M. 2011. Amelia II : A Program for Missing Data. Journal of Statistical Software 45(7):1-54.

Ingemarson, F., Lindhagen, A. and Eriksson, L. 2006. A typology of small-scale private forest owners in Sweden. Scandinavian Journal of Forest Research 21(3):249-259.

Karppinen, H. 1998. Values and Objectives of Non-industrial Private Forest Owners in Finland. Silvia Fennica 32(1):43-59. 
Kendra, A. and Hull, R.B. 2005. Motivations and Behaviors of New Forest Owners in Virginia. Forest Science 51(2):142-154.

Kilgore, M.A., Snyder, S.A., Schertz, J. and Taff, S.J. 2008a. What does it take to get family forest owners to enroll in a forest stewardship-type program? Forest Policy and Economics 10(7-8):507-514.

Kilgore, M.A., Snyder, S., Taff, S. and Schertz, J. 2008b. Family Forest Stewardship: Do Owners Need a Financial Incentive? Journal of Forestry 106(7):357-362.

King, G., Honaker, J., Joseph, A. and Scheve, K. 2001. Analyzing Incomplete Political Science Data: An Alternative Algorithm for Multiple Imputation. American Political Science Review 95(1):49-69.

Kline, J.D., Alig, R.J. and Johnson, R.L. 2000. Forest owner incentives to protect riparian habitat. Ecological Economics 33(1):29-43.

Layton, D.F. and Siikamäki, J. 2009. Payments for Ecosystem Services Programs: Predicting Landowner Enrollment and Opportunity Cost Using a Beta-Binomial Model. Environmental and Resource Economics 44(3):415-439.

Lindhjem, H. and Mitani, Y. 2012. Forest owners' willingness to accept compensation for voluntary conservation: A contingent valuation approach. Journal of Forest Economics 18(4):290-302.

List, J.A. and Gallet, C.A. 2001. What Experimental Protocol Influence Disparities Between Actual and Hypothetical Stated Values? Environmental and Resource Economics 20(3):241254.

Little, T.D., Jorgensen, T.D., Lang, K.M. and Moore, E.W.G. 2014. On the Joys of Missing Data. Journal of Pediatric Psychology 39(2):151-162.

Manly, C.A. and Wells, R.S. 2012. Multiple Imputation and Higher Education Research. NERA Conference Proceedings 2012. Paper 19.

Mäntymaa, E., Juutinen, A., Mönkkönen, M. and Svento, R. 2009. Participation and compensation claims in voluntary forest conservation: A case of privately owned forests in Finland. Forest Policy and Economics 11(7):498-507.

Markowski-Lindsay, M., Stevens, T., Kittredge, D.B., Butler, B.J., Catanzaro, P. and Dickinson, B.J. 2011. Barriers to Massachusetts forest landowner participation in carbon markets. Ecological Economics 71:180-190.

Miller, K.A., Snyder, S.A. and Kilgore, M.A. 2012. An assessment of forest landowner interest in selling forest carbon credits in the Lake States, USA. Forest Policy and Economics 25:113-122.

Murphy, J.J., Allen, P.G., Stevens, T.H. and Weatherhead, D. 2005. A Meta-analysis of Hypothetical Bias in Stated Preference Valuation. Environmental and Resource Economics 30(3):313-325. 

Associations. Available online: http://www.nordicforestry.org/facts/Norway.asp

Norwegian Climate and Pollution Agency. 2010. Climate Cure 2020: Measures and Instruments for achieving Norwegian Climate Goals by 2020. TA 2678/2010. Available online: http://www.miljodirektoratet.no/old/klif/publikasjoner/2678/ta2678.pdf

Norwegian Ministry of Agriculture and Food. 2009. Climate Challenges - Agriculture part of the Solution - Summary in English: Report No. 39 (2008 - 2009) to the Storting. Available online: https://www.regjeringen.no/en/dokumenter/report-no.-39-to-the-storting-20082009/id563671/

Norwegian Ministry of Climate and Environment. 2015. Meld. St. 13 (2014-2015): Ny utslippsforpliktelse for 2030 - en felles løsning med EU. Available online: https://www.regjeringen.no/nb/dokumenter/meld.-st.-13-2014-2015/id2394579/

Norwegian Ministry of the Environment. 2008. Norwegian National Allocation Plan for the Emissions Trading System in 2008-2012. Available online: https://www.regjeringen.no/globalassets/upload/md/vedlegg/planer/nap_final_esa_260308.pd $\mathrm{f}$

Norwegian Ministry of the Environment. 2012. Norwegian Climate Policy: Report No. 21 (2011-2012) to the Storting (white paper) Summary. Available online: https://www.regjeringen.no/contentassets/aa70cfe177d2433192570893d72b117a/engb/pdfs/stm201120120021000en_pdfs.pdf

Nunery, J.S. and Keeton, W.S. 2010. Forest carbon storage in the northeastern United States: Net effects of harvesting frequency, post-harvest retention, and wood products. Forest Ecology and Management 259(8):1363-1375.

Owen, M., Imai, K., King, G. and Lau, O. 2013. Zelig: Everyone's Statistical Software. R package version 4.2-1. Available online: http://cran.rproject.org/web/packages/Zelig/index.html

Pan, Y., Birdsey, R.A., Fang, J., Houghton, R., Kauppi, P.E., Kurz, W.A., Phillips, O.L., Shvidenko, A., Lewis, S.L., Canadell, J.G., Ciais, P., Jackson, R.B., Pacala, S., McGuire, A.D., Piao, S., Rautiainen, A., Sitch, S., Hayes, D. 2011. A Large and Persistent Carbon Sink in the World's Forests. Science 333(6045):988-93.

Peng, C.-Y.J., Lee, K.L. and Ingersoll, G.M. 2002. An Introduction to Logistic Regression Analysis and Reporting. The Journal of Educational Research 96(1):3-14.

Rabotyagov, S.S. and Lin, S. 2013. Small forest landowner preferences for working forest conservation contract attributes: A case of Washington State, USA. Journal of Forest Economics 19(3):307-330.

Rasamoelina, M.S., Johnson, J.E. and Hull, R.B. 2010. Adoption of Woodland Management Practices by Private Forest Owners in Virginia. Forest Science 56(5):444-452. 
Rognstad, O. and Steinset, T.A. 2011. Landbruket i Norge 2011: Jordbruk - Skogbruk - Jakt. Statistics Norway, Oslo.

Rubin, D.B. 1987. Multiple Imputation for Nonresponse in Surveys. New York, NY: John Wiley $\&$ Sons.

Ruddell, S., Sampson, R., Smith, M., Giffen, R., Cathcart, J., Hagan, J., Sosland, D., Godbee, J., Heissenbuttel, J., Lovett, S., Helms, J., Price, W., Simpson, R. 2007. The Role for Sustainably Managed Forests in Climate Change Mitigation. Journal of Forestry 105:314319.

Schafer, J.L. and Graham, J.W. 2002. Missing data: Our view of the state of the art. Psychological Methods 7(2):147-177.

Sullivan, J., Amacher, G.S. and Chapman, S. 2005. Forest banking and forest landowners forgoing management rights for guaranteed financial returns. Forest Policy and Economics 7(3):381-392.

Thompson, D.W. and Hansen, E.N. 2012. Factors Affecting the Attitudes of Nonindustrial Private Forest Landowners Regarding Carbon Sequestration and Trading. Journal of Forestry 110(3):129-137.

Trømborg, E., Sjølie, H.K., Bergseng, E., Bolkesjø, T.F., Hofstad, O., Rørstad, P.K., Solberg, B. and Sunde, K. 2011. Carbon cycle effects of different strategies for utilisation of forest resources - a review. INA fagrapport 19. Department of Ecology and Natural Resource Management, Norwegian University of Life Sciences.

von Hippel, P.T. 2012. Should a Normal Imputation Model be Modified to Impute Skewed Variables? Sociological Methods \& Research. 42(1):105-138.

White, I.R., Royston, P. and Wood, A.M. 2011. Multiple imputation using chained equations: Issues and guidance for practice. Statistics in Medicine 30(4):377-399. 
Figure 1: Estimated participation by payment amount for Model 1 and Model 2.

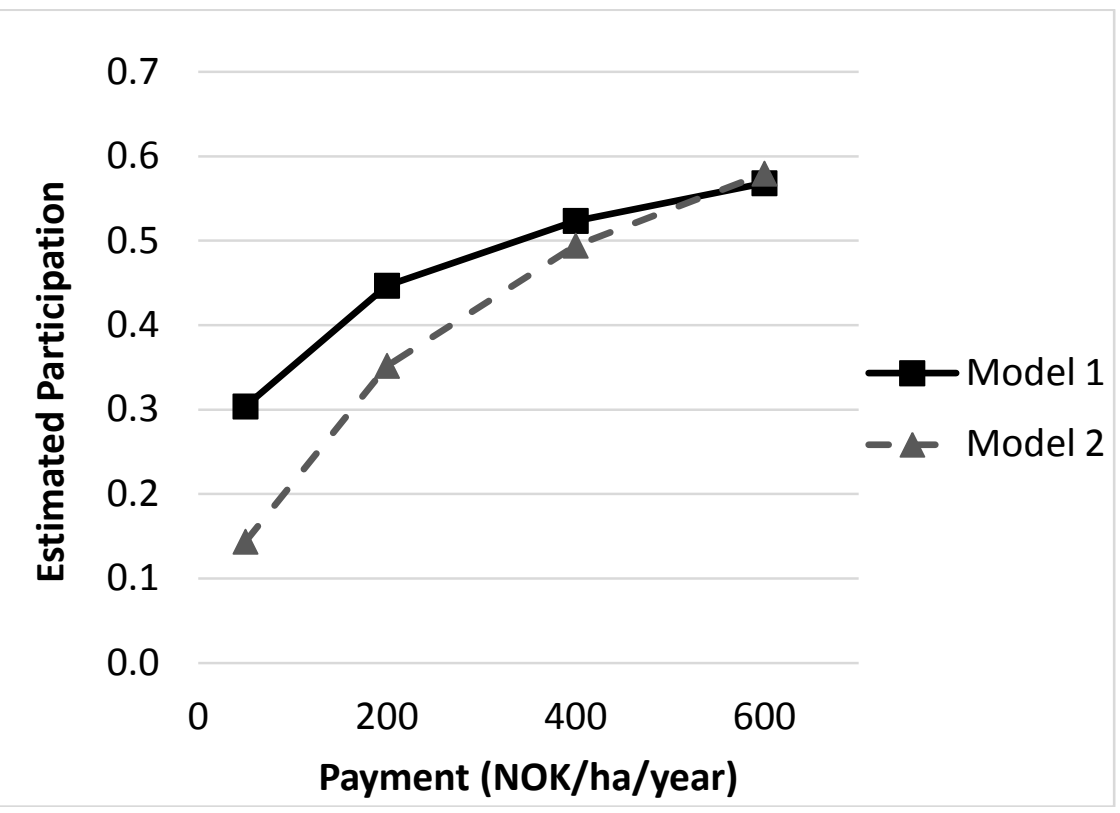


Table 1: Description of variables hypothesized to affect participation in carbon programs.

\begin{tabular}{|c|c|c|}
\hline Variable & Description & $\begin{array}{l}\text { Hypothesized effect } \\
\text { on participation }\end{array}$ \\
\hline \multicolumn{3}{|c|}{ Carbon program characteristics } \\
\hline PAYMENT & $\begin{array}{l}\text { Categorical variable indicating the payment amount offered ( } 50 \text {, } \\
200,400 \text {, or } 600 \mathrm{NOK} / \mathrm{hectare} / \mathrm{year})\end{array}$ & Positive \\
\hline YEARS & $\begin{array}{l}\text { Categorical variable indicating the contract length required }(10,25 \text {, } \\
\text { or } 50 \text { years) }\end{array}$ & Negative \\
\hline \multicolumn{3}{|c|}{ Forestland characteristics } \\
\hline HECTARES & $\begin{array}{l}\text { Continuous variable indicating the total amount of forestland } \\
\text { owned in hectares }\end{array}$ & Uncertain \\
\hline HARVEST & $\begin{array}{l}\text { Binary variable indicating whether the respondent has harvested } \\
\text { timber in the past }\end{array}$ & Positive \\
\hline \multicolumn{3}{|c|}{ Landowner characteristics } \\
\hline MALE & Binary variable indicating the gender of the respondent $(1=$ male $)$ & Uncertain \\
\hline HIGHER.ED & $\begin{array}{l}\text { Binary variable indicating whether the respondent has attained } \\
\text { education beyond a high school diploma }\end{array}$ & Positive \\
\hline TENURE & Continuous variable indicating length of ownership & Negative \\
\hline RESIDE & $\begin{array}{l}\text { Binary variable indicating whether the respondent resides on or } \\
\text { within } 10 \mathrm{~km} \text { of their forestland }\end{array}$ & Uncertain \\
\hline FAMILIARITY & $\begin{array}{l}\text { Categorical variable indicating the respondent's level of familiarity } \\
\text { with managing forests for carbon sequestration }\end{array}$ & Positive \\
\hline OTHER.INCOME & $\begin{array}{l}\text { Categorical variable indicating importance of generating non- } \\
\text { timber income from the forestland }\end{array}$ & Positive \\
\hline NON.MARKET & $\begin{array}{l}\text { Continuous (composite) variable indicating the importance of non- } \\
\text { market forest amenities (e.g. soil and water quality, aesthetics, } \\
\text { biodiversity) }\end{array}$ & Positive \\
\hline BARRIERS & $\begin{array}{l}\text { Continuous (composite) variable indicating the extent to which } \\
\text { various required actions are perceived as barriers to participation }\end{array}$ & Negative \\
\hline CO2.COMP & $\begin{array}{l}\text { Continuous (composite) variable indicating the respondents } \\
\text { attitudes towards climate change and using forests to mitigate } \\
\text { climate change }\end{array}$ & Positive \\
\hline
\end{tabular}


Table 2: Mean values for population, gross sample, and net sample.

\begin{tabular}{|llll|}
\hline Variable & Population & Gross sample & Net sample \\
\hline Age (years) & 56.0 & 55.4 & 55.2 \\
Male & $77 \%$ & $78 \%$ & $81 \%$ \\
Harvested timber in 2011 & $15 \%$ & $29 \%$ & $34 \%$ \\
Live on forest property & $63.6 \%$ & $64.1 \%$ & $63.5 \%$ \\
Total forest area owned (ha) & 85.3 & 221.9 & 265.7 \\
\hline
\end{tabular}


Table 3: Mean values and standard deviations (in brackets) for sample subsets.

\begin{tabular}{|c|c|c|c|c|}
\hline & $\begin{array}{l}\text { Model } 1 \\
\text { All } \\
\text { respondents } \\
(\mathrm{n}=831)\end{array}$ & $\begin{array}{l}\text { Model } 2 \\
\text { Certain } \\
\text { respondents } \\
(\mathrm{n}=394)\end{array}$ & $\begin{array}{l}\text { Model } 3 \\
\text { Large acreage } \\
\text { landowners } \\
(>150 \mathrm{ha}) \\
(\mathrm{n}=385)\end{array}$ & $\begin{array}{l}\text { Model } 4 \\
\text { Small acreage } \\
\text { landowners } \\
(<=150 \text { ha }) \\
(\mathrm{n}=387)\end{array}$ \\
\hline Would accept contract conditions & $48 \%$ & $51 \%$ & $56 \%$ & $43 \%$ \\
\hline Age (years) & $\begin{array}{r}55.4 \\
(12.2)\end{array}$ & $\begin{array}{r}54.2 \\
(11.4)\end{array}$ & $\begin{array}{r}54.4 \\
(11.5)\end{array}$ & $\begin{array}{r}55.7 \\
(12.9)\end{array}$ \\
\hline Male & $83 \%$ & $84 \%$ & $85 \%$ & $81 \%$ \\
\hline Have education beyond high school & $43 \%$ & $51 \%$ & $47 \%$ & $41 \%$ \\
\hline Length of ownership (years) & $\begin{array}{r}22.0 \\
(13.3)\end{array}$ & $\begin{array}{r}21.4 \\
(12.8)\end{array}$ & $\begin{array}{r}22.3 \\
(12.3)\end{array}$ & $\begin{array}{r}21.4 \\
(14.2)\end{array}$ \\
\hline $\begin{array}{l}\text { Reside on or within } 10 \mathrm{~km} \text { of forest } \\
\text { property }\end{array}$ & $82 \%$ & $82 \%$ & $84 \%$ & $81 \%$ \\
\hline Member of forest owner association & $73 \%$ & $72 \%$ & $86 \%$ & $62 \%$ \\
\hline Forestland owned (hectares) & $\begin{array}{r}319.3 \\
(1694.5)\end{array}$ & $\begin{array}{r}426.4 \\
(2423.2)\end{array}$ & $\begin{array}{r}564.8 \\
(2379.7)\end{array}$ & $\begin{array}{r}75.0 \\
(45.1)\end{array}$ \\
\hline Previously harvested timber for sale & $78 \%$ & $80 \%$ & $90 \%$ & $69 \%$ \\
\hline Forest certified during the past 10 years & $66 \%$ & $68 \%$ & $81 \%$ & $57 \%$ \\
\hline $\begin{array}{l}\text { Prepared a management plan during the } \\
\text { past } 10 \text { years }\end{array}$ & $61 \%$ & $62 \%$ & $75 \%$ & $50 \%$ \\
\hline $\begin{array}{l}\text { Implemented management measures } \\
\text { during the past } 10 \text { years }\end{array}$ & $65 \%$ & $69 \%$ & $80 \%$ & $53 \%$ \\
\hline
\end{tabular}


Table 4: Regression coefficients and standard errors (in brackets) of factors influencing Norwegian family forest owner participation in carbon programs.

\begin{tabular}{|c|c|c|c|c|c|}
\hline Variable & Description & $\begin{array}{l}\text { Model 1 } \\
\text { All } \\
\text { respondents } \\
(n=831)\end{array}$ & $\begin{array}{l}\text { Model } 2 \\
\text { Certain } \\
\text { respondents } \\
(n=394)\end{array}$ & $\begin{array}{l}\text { Model } 3 \\
\text { Large acreage } \\
\text { landowners } \\
(>150 \mathrm{ha}) \\
(\mathrm{n}=385)\end{array}$ & $\begin{array}{l}\text { Model } 4 \\
\text { Small acreage } \\
\text { landowners } \\
(<=150 \text { ha }) \\
(n=387)\end{array}$ \\
\hline \multicolumn{6}{|c|}{ Carbon program characteristics } \\
\hline InPAYMENT & Payment amount offered & $\begin{array}{l}0.4442 * * * \\
(0.0957)\end{array}$ & $\begin{array}{l}0.8477 * * * \\
(0.1664)\end{array}$ & $\begin{array}{l}0.5187 * * * \\
(0.1458)\end{array}$ & $\begin{array}{l}0.4346 * * * \\
(0.1477)\end{array}$ \\
\hline YEARS & Contract length required & $\begin{array}{l}-0.0049 \\
(0.0054)\end{array}$ & $\begin{array}{l}-0.0111 \\
(0.0093)\end{array}$ & $\begin{array}{l}-0.0110 \\
(0.0085)\end{array}$ & $\begin{array}{l}-0.0080 \\
(0.0084)\end{array}$ \\
\hline \multicolumn{6}{|c|}{ Forestland characteristics } \\
\hline InHECTARES & Forestland owned & $\begin{array}{l}0.1600 * \\
(0.0900)\end{array}$ & $\begin{array}{l}0.1652 \\
(0.1575)\end{array}$ & $\begin{array}{l}0.0285 \\
(0.2223)\end{array}$ & $\begin{array}{l}0.1815 \\
(0.1770)\end{array}$ \\
\hline HARVEST & $\begin{array}{l}\text { Harvested timber in the } \\
\text { past }\end{array}$ & $\begin{array}{l}-0.3299 \\
(0.2603)\end{array}$ & $\begin{array}{l}-0.5771 \\
(0.4387)\end{array}$ & $\begin{array}{l}-0.9869 * * \\
(0.5001)\end{array}$ & $\begin{array}{l}-0.1906 \\
(0.3417)\end{array}$ \\
\hline \multicolumn{6}{|c|}{ Landowner characteristics } \\
\hline MALE & Respondent is male & $\begin{array}{l}-0.1692 \\
(0.2530)\end{array}$ & $\begin{array}{l}-0.0042 \\
(0.4272)\end{array}$ & $\begin{array}{l}-0.4291 \\
(0.3913)\end{array}$ & $\begin{array}{l}0.1447 \\
(0.3957)\end{array}$ \\
\hline HIGHER.ED & $\begin{array}{l}\text { Respondent has higher } \\
\text { education }\end{array}$ & $\begin{array}{l}0.4841 * * \\
(0.1881)\end{array}$ & $\begin{array}{l}0.7348 * * \\
(0.3288)\end{array}$ & $\begin{array}{l}0.2199 \\
(0.2937)\end{array}$ & $\begin{array}{l}0.6367 * * \\
(0.2893)\end{array}$ \\
\hline TENURE & Length of ownership & $\begin{array}{l}-0.0045 \\
(0.0069)\end{array}$ & $\begin{array}{l}0.0104 \\
(0.0124)\end{array}$ & $\begin{array}{l}-0.0071 \\
(0.0111)\end{array}$ & $\begin{array}{l}0.0004 \\
(0.0104)\end{array}$ \\
\hline RESIDE & $\begin{array}{l}\text { Respondent resides on } \\
\text { the forestland }\end{array}$ & $\begin{array}{l}-0.1714 \\
(0.2520)\end{array}$ & $\begin{array}{l}0.6058 \\
(0.4246)\end{array}$ & $\begin{array}{l}-0.6496 \\
(0.4082)\end{array}$ & $\begin{array}{l}0.0240 \\
(0.3763)\end{array}$ \\
\hline FAMILIARITY & $\begin{array}{l}\text { Familiarity with carbon } \\
\text { offsets }\end{array}$ & $\begin{array}{l}0.0064 \\
(0.0925)\end{array}$ & $\begin{array}{l}0.0108 \\
(0.1541)\end{array}$ & $\begin{array}{l}0.0101 \\
(0.1500)\end{array}$ & $\begin{array}{l}0.0234 \\
(0.1473)\end{array}$ \\
\hline OTHER.INCOME & $\begin{array}{l}\text { Importance of non- } \\
\text { timber income }\end{array}$ & $\begin{array}{l}0.0315 \\
(0.0728)\end{array}$ & $\begin{array}{l}0.0000 \\
(0.1164)\end{array}$ & $\begin{array}{l}-0.0306 \\
(0.1129)\end{array}$ & $\begin{array}{l}0.0944 \\
(0.1176)\end{array}$ \\
\hline NON.MARKET & $\begin{array}{l}\text { Importance of non- } \\
\text { market forest amenities }\end{array}$ & $\begin{array}{l}-0.2603 * * \\
(0.1233)\end{array}$ & $\begin{array}{l}-0.3835 * \\
(0.2162)\end{array}$ & $\begin{array}{l}-0.6040 * * * \\
(0.2139)\end{array}$ & $\begin{array}{l}-0.2788 \\
(0.1979)\end{array}$ \\
\hline BARRIERS & $\begin{array}{l}\text { Barriers posed by } \\
\text { management actions }\end{array}$ & $\begin{array}{l}-1.4724 * * * \\
(0.1398)\end{array}$ & $\begin{array}{l}-1.9347 * * * \\
(0.2383)\end{array}$ & $\begin{array}{l}-2.0113 * * * \\
(0.2585)\end{array}$ & $\begin{array}{l}-1.5249 * * * \\
(0.2081)\end{array}$ \\
\hline CO2.COMP & $\begin{array}{l}\text { Attitudes towards } \\
\text { climate change }\end{array}$ & $\begin{array}{l}0.3890 * * * \\
(0.1148)\end{array}$ & $\begin{array}{l}0.6836 * * * \\
(0.1931)\end{array}$ & $\begin{array}{l}0.4500 * * \\
(0.1839) \\
\end{array}$ & $\begin{array}{l}0.4859 * * * \\
(0.1705)\end{array}$ \\
\hline Goodness-of-fit st & $\operatorname{tics}^{I}$ & & & & \\
\hline Null deviance & & 1150.82 & 545.86 & 527.41 & 528.76 \\
\hline Residual deviance & & 831.50 & 300.42 & 345.83 & 376.49 \\
\hline $\begin{array}{l}\text { AIC } \\
\text { Significance levels: }\end{array}$ & $1 \%, * * 5 \%, * 10 \%$ & 859.50 & 328.42 & 373.83 & 404.49 \\
\hline
\end{tabular}

\footnotetext{
${ }^{1}$ Goodness-of-fit statistics were averaged across the multiply imputed datasets.
} 
Table 5: Marginal effects of factors influencing Norwegian family forest owner participation in carbon programs.

\begin{tabular}{|c|c|c|c|c|c|}
\hline Variable & Description & $\begin{array}{l}\text { Model } 1 \\
\text { All } \\
\text { respondents } \\
(\mathrm{n}=831)\end{array}$ & $\begin{array}{l}\text { Model } 2 \\
\text { Only certain } \\
\text { respondents } \\
(\mathrm{n}=394)\end{array}$ & $\begin{array}{l}\text { Model } 3 \\
\text { Large acreage } \\
\text { landowners } \\
(>150 \text { ha) } \\
(\mathrm{n}=385)\end{array}$ & $\begin{array}{l}\text { Model } 4 \\
\text { Small acreage } \\
\text { landowners } \\
(<=150 \text { ha }) \\
(\mathrm{n}=387)\end{array}$ \\
\hline \multicolumn{6}{|c|}{ Carbon program characteristics } \\
\hline InPAYMENT & Payment amount offered & $0.1102 * * *$ & $0.2117 * * *$ & $0.1249 * * *$ & $0.1026 * * *$ \\
\hline YEARS & Contract length required & -0.0012 & -0.0028 & -0.0026 & -0.0019 \\
\hline \multicolumn{6}{|c|}{ Forestland characteristics } \\
\hline InHECTARES & Forestland owned & $0.0397^{*}$ & 0.0412 & 0.0069 & 0.0428 \\
\hline $\begin{array}{l}\text { HARVEST } \\
\text { Landowner charact }\end{array}$ & $\begin{array}{l}\text { Harvested timber in the } \\
\text { past } \\
\text { ristics }\end{array}$ & -0.0819 & -0.1441 & $-0.2376 * *$ & -0.0450 \\
\hline MALE & Respondent is male & -0.0420 & -0.0010 & -0.1033 & 0.0342 \\
\hline HIGHER.ED & $\begin{array}{l}\text { Respondent has higher } \\
\text { education }\end{array}$ & $0.1201 * *$ & $0.1835 * *$ & 0.0529 & $0.1503 * *$ \\
\hline TENURE & Length of ownership & -0.0011 & 0.0026 & -0.0017 & 0.0001 \\
\hline RESIDE & $\begin{array}{l}\text { Respondent resides on } \\
\text { the forestland }\end{array}$ & -0.0425 & 0.1513 & -0.1564 & 0.0057 \\
\hline FAMILIARITY & $\begin{array}{l}\text { Familiarity with carbon } \\
\text { offsets }\end{array}$ & 0.0016 & 0.0027 & 0.0024 & 0.0055 \\
\hline OTHER.INCOME & $\begin{array}{l}\text { Importance of non- } \\
\text { timber income }\end{array}$ & 0.0078 & 0.0000 & -0.0074 & 0.0223 \\
\hline NON.MARKET & $\begin{array}{l}\text { Importance of non- } \\
\text { market forest amenities }\end{array}$ & $-0.0646 * *$ & $-0.0957 *$ & $-0.1454 * * *$ & -0.0658 \\
\hline BARRIERS & $\begin{array}{l}\text { Barriers posed by } \\
\text { management actions }\end{array}$ & $-0.3654 * * *$ & $-0.4830 * * *$ & $-0.4842 * * *$ & $-0.3599 * * *$ \\
\hline CO2.COMP & $\begin{array}{l}\text { Attitudes towards } \\
\text { climate change }\end{array}$ & $0.0965 * * *$ & $0.1707 * * *$ & $0.1083^{* *}$ & $0.1147 * * *$ \\
\hline
\end{tabular}

